\title{
THE DEVELOPMENT OF DECIDUOMATA INDUCED BY TWO NON-TRAUMATIC METHODS IN THE MOUSE
}

\author{
C. M. HETHERINGTON \\ Institute of Animal Genetics, Edinburgh
}

(Received 17th April 1968, accepted 25th June 1968)

In the mouse at implantation, the uterus responds to the presence of a blastocyst by producing a massive cellular reaction in the stroma to form a deciduoma. The period during which the decidual cell reaction may be initiated is fairly well defined, and the reaction depends on adequate sensitization of the uterus by the ovarian hormones. In this study, two non-traumatic methods of deciduoma induction were employed, intra-luminal injection of arachis oil (Finn \& Hinchliffe, 1965), and intra-luminal injection of air, which was reported by Orsini (1963) to be an effective stimulus in the hamster and the rat.

Virgin mice of the random outbred Q strain, weighing 20-25 g, and pseudopregnant after mating with vasectomized males, were used. The day on which the vaginal plug was found was taken as the 1st day of pseudopregnancy. The first experiment was designed to discover the time of onset and duration of uterine sensitivity. The treatment, which was restricted to one horn of each uterus, consisted of an intraluminal injection, through the utero-tubal junction, using a $30 \mathrm{G}$ needle and a $0.05 \mathrm{ml}$ microlitre syringe, of either $0.01 \mathrm{ml}$ of arachis oil on one of the first 5 days of pseudopregnancy at 09.30 or 16.30 hours, or $0.02 \mathrm{ml}$ of air on the 3rd, 4th or 5th day-each experimental group consisting of five mice. In order to determine the extent of traumatic deciduoma, a syringe needle was merely inserted into one horn of each of the control group. Autopsies, in all instances, were carried out between 11.00 and 11.30 hours on the 7th day, and the uterine horns were weighed individually on a torsion balance.

It was apparent at autopsy that some inter-cornual migration of both oil and air had occurred, making a between-horn comparison impossible, while traumatic deciduomata in the control horns were small or absent. With the doses used, oil produced the greater response (Text-fig. 1). The data suggest either that the period of sensitivity for induction by oil is of longer duration or, more probably, that the oil remains longer in the lumen. If $0.02 \mathrm{ml}$ of air is injected into a uterine horn, air bubbles may be detected, on dissecting the uterus under physiological saline, for up to $5 \mathrm{hr}$. Oil may be similarly detected in a uterus for 5 days, after injection on the 4th day of pseudopregnancy. Oil injected on the lst day of pseudopregnancy, however, produced only one small deciduoma in one of five treated horns. Probably oil injected on the 1st day of pseudopregnancy is able to leak out of the vagina, while oil injected on the 4th day of pseudopregnancy is trapped by the deciduoma. The data suggest that 


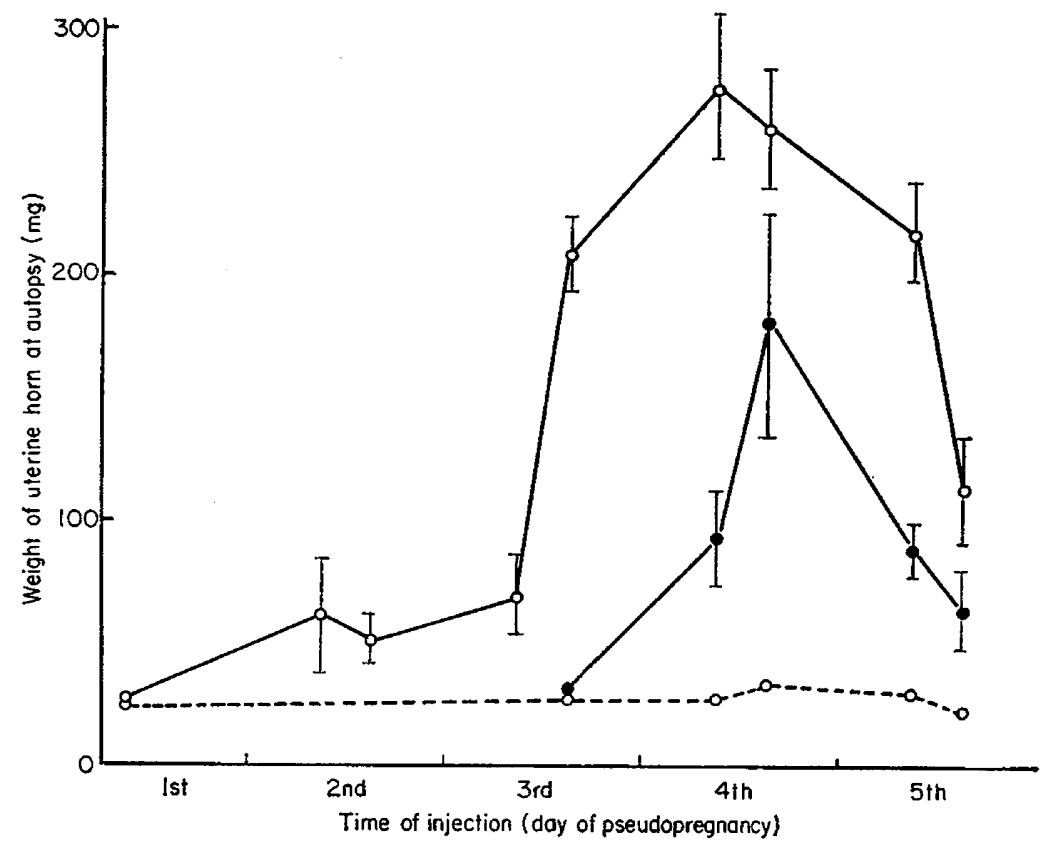

TexT-FIG. 1. Relationship between day of injection and weight of treated uterine horn on the 7 th day of pseudopregnancy. Vertical bars, \pm 1 standard error; 0 , Oil; 9 , air; ,---- control.

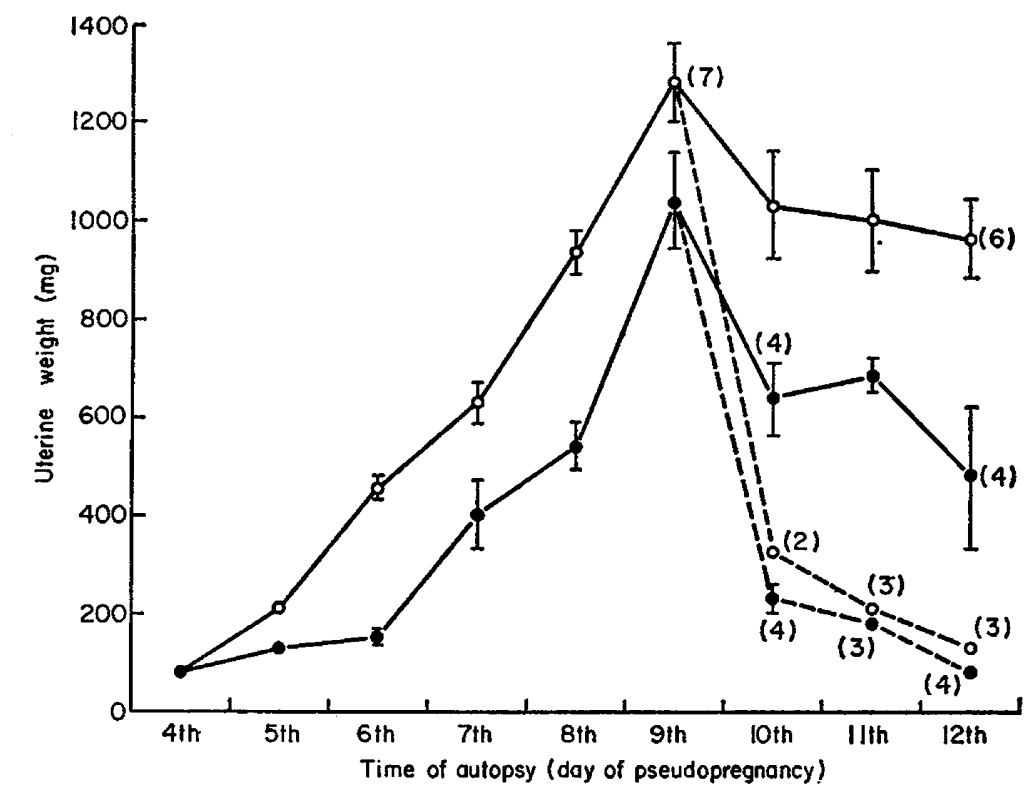

TEXT-Fig. 2. Change in uterine weight after deciduoma induction on the 4th day of pseudopregnancy by arachis oil $(0)$, or air ( $)$. Vertical bars, \pm 1 standard error; ,--- uteri without moles. Group size 5 unless shown in parentheses. 
the uterus becomes sensitive both to air and oil during the afternoon of the 4th day; air injected during the morning of the 4th day and oil injected from the 2nd day onwards, are still present at the beginning of the sensitive period in sufficient amount to elicit a decidual response. By 09.30 hours on the 5 th day, the sensitivity of the uterus is reduced. This was confirmed in an experiment in which mice were killed at 11.30 hours, 2 days after air injection on the 4th, 5 th and 6th day of pseudopregnancy. The mean uterine weights were $155.4 \pm$ $13.9 \mathrm{mg}, 113.2 \pm 26.8 \mathrm{mg}$ and $92.6 \pm 24.7 \mathrm{mg}$, respectively (least significant difference $14.5 \mathrm{mg} P=0.01$ ).

In a second experiment, either $0.01 \mathrm{ml}$ arachis oil or $0.02 \mathrm{ml}$ air was injected into each uterine horn between 13.00 and 13.30 hours on the 4th day of pseudopregnancy, and the mice were killed at 11.30 hours on the 4th to 12th days. Decidual growth was similar in both instances, reaching a peak on the 9 th day. From the 9th day onwards necrosis occurred. Necrotic decidual tissue was found free in the uterine lumen forming 'moles', the incidence of which decreased with time.

These results are similar to those of Atkinson (1944) on traumatically induced deciduomata, but in his strain of mice necrosis occurred on the 8th day of pseudopregnancy rather than on the 9 th.

The response of the uterus to the presence of oil or air is thus similar in that it is first evident during the afternoon of the 4th day. Oil remains longer in the lumen, and is thus more suitable for the comparison of deciduomata induced in different strains, where the period of sensitivity may not be identical.

I should like to thank Dr Anne McLaren for helpful suggestions and comments during the course of this work, and acknowledge a grant from the Medical Research Council.

\section{REFERENCES}

Atrinson, W. B. (1944) The persistence of deciduomata in the mouse. Anat. Rec. 88, 271.

FinN, C. A. \& Hinchlifre, J. R. (1965) Histological and histochemical analysis of the formation of implantation chambers in the mouse uterus. F. Reprod. Fert. 9, 301.

OrSINI, M. (1963) Induction of deciduomata in hamster and rat by injected air. F. Endocr. 28, 119. 